\title{
Student Motivation and Its Correlation with French Learning Outcomes During the Covid- 19 Outbreak
}

\author{
Indah Nevira Trisna \\ Pendidikan Bahasa Prancis \\ Universitas Lampung \\ Bandar Lampung, Indonesia \\ indah.nevira@fkip.unila.ac.id
}

\author{
Nani Kusrini \\ Pendidikan Bahasa Prancis \\ Universitas Lampung \\ Bandar Lampung, Indonesia \\ nani.kusrini@fkip.unila.ac.id
}

\begin{abstract}
Motivation is considered as one of the factors that determine success, especially in learning a second language. On the other hand, learning outcomes are a measure of the success of the teaching and learning process. This study aims to describe students' motivation to learn French during distance learning of the COVID-19 outbreak and to reveal the correlation between these motivations and student learning outcomes. This research is descriptive quantitative research. Respondents in this study were 164 grade $X$ students from two high schools (SMA) in Lampung. The instrument used was a closed questionnaire using a Likert scale and interviews which were arranged by adapting the learning motivation theory of Hamzah $B$. Uno and Sardiman. The results of the analysis showed that the students' learning motivation of 79.7 was included in the high category. Meanwhile, through a series of tests and hypothesis testing using the Pearson correlation formula with the help of SPSS 19, it can be concluded that there is a positive correlation between motivation and learning outcomes during online learning during the Covid-19 pandemic. The coefficient value of 0.224 is interpreted that the correlation between the two variables being in a low category.
\end{abstract}

Keywords-French learning, motivation, learning outcomes, distance learning

\section{INTRODUCTION}

Studies that examine the determinants of success in language learning, especially second (foreign) languages are still the interest of many researchers because the transformations that occur both from within and outside greatly affect the existing conditions. Language attitudes and motivation are two of these determinants (Gardner and Clement, 1990; Lambert, 1963 cited in $[1 ; 2 ; 8 ; 3])$

Gardner and Clement (1990) focus on the social psychology aspect by proposing three variables that influence second language acquisition, namely cognitive, attitude, and motivational characteristics as well as personality. A similar opinion was also conveyed by Lambert (1963) in [1] who emphasized that a person's success in acquiring a second language depends on motivation, attitude, and orientation towards language learning. [2] also mentions several variables that influence language learning, including the level of learner development, age, attitude, and motivation. Furthermore, a more detailed explanation to strengthen these opinions was conveyed by Brown (1980) in [3] that in the study of language learning, several factors influence language mastery: 1) innate factors such as talent (aptitude), 2) factors general terms such as attitude and motivation and 3) cognitive style. It can be concluded that among the factors mentioned, motivation and attitude are dominant factors related to second language acquisition.

Motivation is related to the factors that encourage a person to take any action while attitude can be interpreted as a tendency to act to form real behavior. A very close relationship between attitude and motivation is explained by Gardner (1985) in [4] who says that motivation refers to a combination of effort plus a desire to achieve language learning goals plus a positive attitude towards language learning. Although initially both were considered as dominant factors in the success of language learning, nowadays attitudes are seen as motivational support such as talent, intelligence, interest and not as a factor that has a direct influence on learning a second language [5]. This is also confirmed by [6] that the core of the study of language attitudes is the motivation of students in learning the language.

The word motivation is often used to describe a person's success and failure in a business. The importance of motivation in the success of second language learning is recognized by both teachers and researchers [6] On the other hand, motivation also has a social aspect because it relates to the users of the language being studied, teachers, society, work, goals, and other learning motivators. Because of this external 
nature, motivation can change during language learning. It can be modified, influenced to achieve learning goals.

Factors that influence second language learning are divided into two: internal and external. Internal factors include motivation, intelligence, anxiety, ability to take risks, and so on, while external factors are related to variables such as social class, teachers, learning start time, language teaching curriculum, and so on. Many studies show that motivation is closely related to language skills. Motivation is believed to be an important variable that determines success and achievement in learning a second language. Motivation is believed to act like a machine that generates learning and then pushes students forward helping them overcome the difficulties they face in learning a foreign language [30;31]. [7] considers motivation as an effective factor that plays an important role in learning a second or foreign language.

The pandemic that has been lasting since early 2020 has had a major impact on the world in all sectors of life. The world is required to adjust to the new normal. To minimize the spread of the coronavirus, the world has implemented physical distancing policies that limit direct social interaction. This is what ultimately underlies the issue of the circular letter of the Minister of Education No. 3 of 2020 concerning the prevention of the coronavirus disease (covid 19) in education units and also circular letter No. 4 of 2020 regarding the implementation of learning from home through online/distance learning.

Restrictions on the interaction between teachers and students as well as the use of distance learning support equipment such as Edmodo, Google Classroom, WhatsApp, and others have changed the study habits and interactions of students and teachers so far. Moore (1983) in [9] states that the distance between students and teachers in learning is not only seen in terms of physical and geographical distance but must be seen as a communication and psychological distance caused by the separation between students and teachers.

This change, of course, caused a surprise for both teachers and students. Teachers are required to provide teaching that is adaptive to circumstances, innovative, and creative in creating distance learning because demands, circumstances, and several other aspects distinguish face-to-face learning from it. In addition, changes in the learning environment carried out at home and unpreparedness for the independent study also affect students' motivation.

Motivation is one of the most important aspects of the success of learning. The effect of online learning on learning motivation during distance learning during the Covid-19 pandemic has attracted many researchers to study it in depth. Some researches yielded different results. Student learning motivation remains good during online learning, among others, because of application support and internet mastery [9;10] Meanwhile, other researches show that students' learning motivation decreases during this pandemic [11]

Distance learning is also applied to French classes in several high schools/vocational schools in Lampung. The implementation of learning French as a second foreign language and including specialization subjects has its characteristics and problems, as stated by the French teacher during this pandemic outbreak based on preliminary observations. While on the other hand, learning achievement is a measure of the success of the teaching and learning process. Therefore, this study aims to describe students' learning motivation during distance learning during the Covid-19 pandemic and its relationship to student learning outcomes. Motivation is one of the central factors for learning success is considered important to be studied more deeply because it affects learning outcomes.

\section{METHOD}

This study has two objectives, namely to describe students' learning motivation during online French learning and to identify the influence of motivation on student learning outcomes. The approach used in this research then is descriptive quantitative research.

The total population in this study was 309 students. By referring to the table for determining the number of samples from Issac and Michael in [12] with an error rate of $5 \%$, the number is 164 . The students from the two schools were determined using a simple random sampling technique. The reason for selecting this sampling technique is based on the results of observations which show that there are no significant differences in the characters from the existing population so that they do not have a significant influence on the results of the analysis.

There are two variables in this study: the dependent variable is student learning outcomes (Y) and the independent variable is student learning motivation (X). Meanwhile, to obtain the necessary data following the research objectives, data collection tools were used, namely instruments in the form of questionnaires and interviews

The questionnaire was used to determine students' motivation to learn French during distance learning. In this study, the learning motivation theory of $[13 ; 14]$ was used as a reference in preparing questions in the questionnaire. Taking into account the suitability of the objectives and conditions of learning French in schools, the indicators used to measure learning motivation is 1) desire and willingness to succeed, 2) encouragement and need for learning, 3) persevere in the face of tasks, 4) tenacious in facing difficulties, 5)interesting activities in learning and 6)conducive learning environment. Each of these indicators is 
developed into 3 items in the form of statements. So, the total items in the questionnaire are 18 and are arranged using a Likert scale with 5 choices, namely a) always, b) often, c) sometimes, d) rarely and e) never.

On the other hand, to find out more in-depth about matters related to student learning motivation during the pandemic period as well as factors related to learning achievement such as the learning process and so on, interviews were used. The interview consisted of 18 questions and was asked to 63 randomly selected students. Meanwhile, to answer the second question, namely how the correlation between motivation and learning outcomes is needed, students' scores for French subjects are needed. The data used as the result of learning French for this research is the result of the PAT (End of Year Assessment) results for the even semester of class $X$ for the 2020/2021 academic year. In addition, the researchers also collected various assignments during the semester as supporting data.

To find out the relationship between motivation and learning outcomes, a hypothesis test was used which had previously been tested for prerequisite analysis, namely the normality test and linearity test. Hypothesis testing was carried out by testing the Product Moment correlation using the SPSS 19 computer program.

\section{RESULTS AND DISCUSSION}

This study uses a questionnaire as a data collection instrument. The instrument, which is intended to measure students' motivation to learn French during the Covid-19 pandemic, was compiled based on a combination of learning motivation theory from Hamzah B. Uno and Sardiman. From the two theories, six indicators are used to measure learning motivation. Each indicator is developed into three statements that are compiled using a Likert scale with 5 choices with different weight values.

A good instrument must be valid and reliable. [12] argues that valid means that the instrument can be used to measure what should be measured. There are two kinds of validity, namely internal validity, and external validity. Internal validity is developed according to the relevant theory while external validity is the degree of accuracy of whether the research results can be generalized or applied to the population where the sample is taken.

Testing the validity of the questionnaire used in this study was conducted on two variables, namely learning motivation (X) and learning outcomes (Y). Test the validity using the $r_{x y}$ coefficient formula using the Product Moment. After the $r_{x y}$ value is obtained then it is distributed into the $r$ test formula where the value of $r$ count $>r$ table with a significance level of $5 \%$ then the item is valid. The validity of this questionnaire is calculated by using SPSS 19. From the analysis, the results obtained are as follows:

TABLE I. RESULT OF VALIDITY TEST

\begin{tabular}{|c|c|c|c|}
\hline No.item & $\mathbf{r}_{\text {count }}$ & $\mathbf{r}_{\text {table }}$ & Description \\
\hline 1 & 0,577 & 0,194 & valid \\
\hline 2 & 0,507 & 0,194 & valid \\
\hline 3 & 0,338 & 0,194 & valid \\
\hline 4 & 0,497 & 0,194 & valid \\
\hline 5 & 0,444 & 0,194 & valid \\
\hline 6 & 0,548 & 0,194 & valid \\
\hline 7 & 0,653 & 0,194 & valid \\
\hline 8 & 0,482 & 0,194 & valid \\
\hline 9 & 0,670 & 0,194 & valid \\
\hline 10 & 0,548 & 0,194 & valid \\
\hline 11 & 0,475 & 0,194 & valid \\
\hline 12 & 0,487 & 0,194 & valid \\
\hline 13 & 0,332 & 0,194 & valid \\
\hline 14 & 0,518 & 0,194 & valid \\
\hline 15 & 0,271 & 0,194 & valid \\
\hline 16 & 0,604 & 0,194 & valid \\
\hline 17 & 0,348 & 0,194 & valid \\
\hline 18 & 0,389 & 0,194 & valid \\
\hline
\end{tabular}

The reliability test is intended to determine the consistency or accuracy of the instrument. The reliability test of the questionnaire was carried out on two variables, namely learning motivation (X) and learning outcomes (Y). This level of constancy is calculated using the Cronbach Alpha formula so that the value of $r=0.789$ is obtained. This coefficient is then interpreted using the criteria from Guilford. From the reliability coefficient classification table above, it can be seen that the results of the reliability calculation $r=0.789$ include a range of $0.60 r<0.80$ which means that the statement items in the questionnaire are reliable with a high interpretation.

\section{A. Learning Motivation}

This research was conducted in the even semester of T.A. 2020/2021 by involving 164 class X students from two schools in Lampung as respondents. The questionnaire used in this study was distributed to students in the form of a google form in mid-July when a new teaching was opened with the excuse of waiting to get the PAT (End of Year Assessment) results from school teachers. Respondents in this study amounted to 164 students, so the number of ideal scores (criteria) for each item is $5 \times 164=820$. To obtain the average value or percentage of each item, the following formula is used:

Score per item $=\left(\frac{\text { Total score per item }}{87.0}\right) \times 100$

Based on the calculation of the results of the questionnaire, the results of calculating the value and percentage per indicator are as follows: 


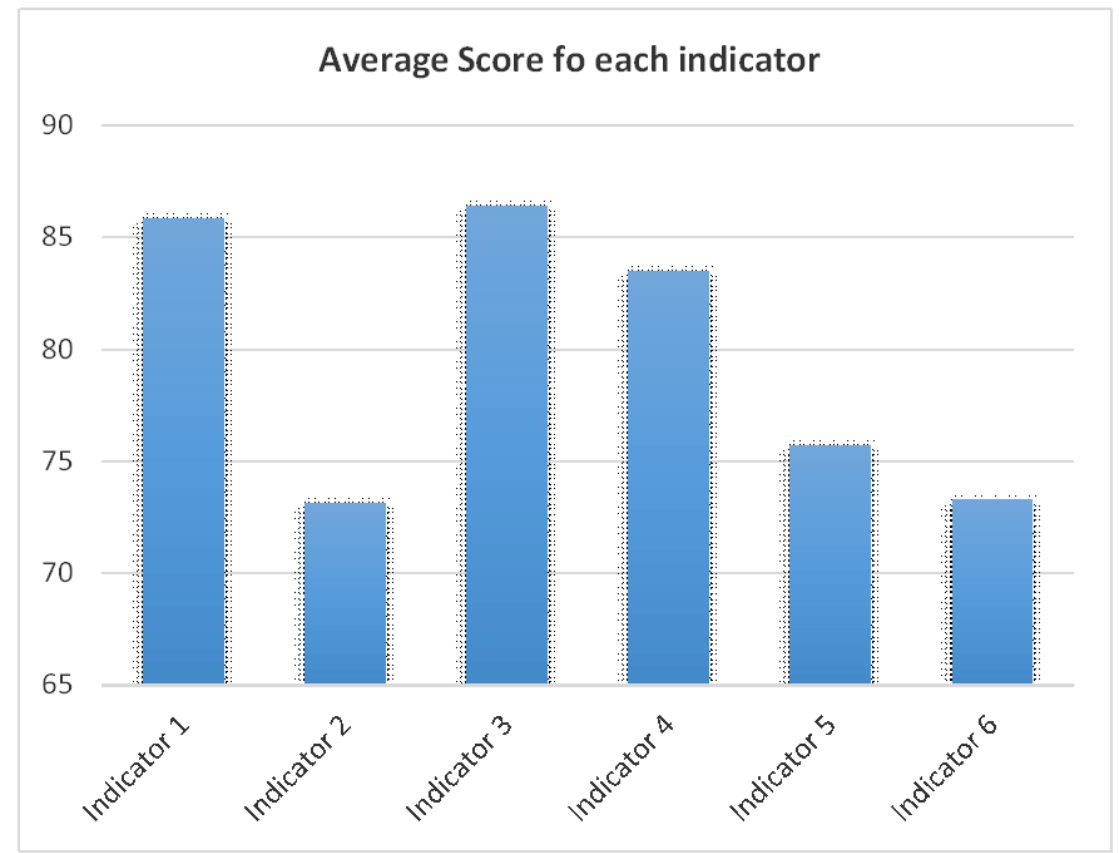

Fig 1. The average score for each indicator

\section{Description :}

Indicator 1: Desire and willingness to succeed

Indicator 2: Encouragement and need in learning

Indicator 3: Persevere in the face of the task

Indicator 4: Tenacious in the face of adversity

Indicator 5: Interesting activities in learning

Indicator 6: Conducive Learning Environment

In addition to questionnaires, this study also used interviews by taking 63 of the total number of respondents to obtain more complete information. Analysis of the results of the questionnaire and interviews are as follows:

\section{1) Desire and willingness to succeed}

The average score of the first indicator is 85.85 . This indicates that students have a very good desire to be successfully shown by always being present in online class learning, participating from beginning to end, and feeling a loss if they miss French class. Most of the students stated that they always attend class, participate from beginning to end of class and often feel like it is a loss if they miss French class.

Online learning in these two high schools is dominated by the use of Google Classroom and also WhatsApp as media. During the semester, the teacher organizes virtual face-to-face learning synchronously through Google Meetings only 4 times. Always present in this context means that students always write attendance in the chat column on Google Classroom on time, and the form of student participation in learning is marked by continuing to listen or read conversations written on WAG. Some students stated that they were not always present due to signal and quota problems.

\section{2) Encouragement and need in learning}

The second aspect used as an indicator is encouragement and the need for learning. Having an average score of 73.17 makes it classified in the good category. Good student motivation in this aspect is shown by students actively participating during online classes. In addition, students also have the initiative to look for other references on the internet about French language material being taught for better mastery. Their active participation is shown by answering or asking questions to the teacher regarding the material during the online class. To understand the material, students generally use Google Translate to add vocabulary or understand a sentence or text, few use learning applications or watch videos on Youtube. In online learning, the teacher provides hand-outs that are distributed through Google Classroom or WAG. Many students reread the material as well as the French handbook after class.

\section{3) Persevere in the face of the task}

Giving assignments is an integral part of learning because it can make students understand the material better. The value for this indicator is 86.46 so it can be interpreted that the enthusiasm of students to work on and complete assignments are high. Many students always do tasks given during online learning French, and generally, they do it independently. Only a small 
number of students asked their friends or seniors for help. Only some sometimes don't do assignments because they don't understand the tasks, have signal problems or a lot of assignments from other lessons, and forget to check Google Classroom.

\section{4) Tenacious in the face of adversity}

This indicator has a score of 83.53. This high level is shown by students who never give up on difficult French assignments. The students also have a desire to improve French grades and contact friends or teachers for missed assignments due to illness or absenteeism

\section{5) Interesting activities in learning}

The fifth indicator used in the questionnaire is the existence of interesting activities in learning. The value for this indicator is 75.73 which can be interpreted well. Respondents think that they are quite motivated when learning French online with fun techniques or teacher teaching methods. Teachers sometimes give games in class. According to students, the media used by teachers is also interesting. The French handbooks owned by students, the use of teaching media such as videos taken from YouTube, French songs, materials in the form of PPT add to the diversity of teaching media. The students find it interesting when teachers explain the culture and civilization of French. Learning a language is not just about grammar and vocabulary. Introducing the culture of speakers of the language being studied can also increase motivation to learn because language is a thing that is intertwined with culture.

\section{6) Conducive Learning Environment}

The establishment of a conducive learning environment is very appropriate for conditions like today. This study shows that students' motivation with a score of 73.29 is in a good category. More than half of the respondents answered a fairly good internet connection and also two-thirds of students chose frequent and always answers that they received support from parents during online learning.

The face-to-face class can be conditioned by the teacher. Everything that interferes with concentration or the learning process can be minimized by the teacher's role. But during online learning, of course, is different. From the results of the interviews, it was found that more than half of the respondents said that the condition of their houses made it possible to study online because students had their rooms or rooms to study without interruption. Meanwhile, a quarter of students said that the atmosphere at their residence was less likely to be caused by noise, for example, a crying sister, frequent power outages.

Online learning is carried out using devices and is carried out remotely. The device used to support online learning for almost all students is a smartphone. Although a third of students have more than one device other than a smartphone such as a computer or a laptop, in practice students prefer a smartphone because it is considered more practical

According to more than half of students, internet connection is quite good. For more than fifty percent of respondents said that purchasing quotas that support online learning are not a problem. The quota assistance from the Ministry of Education and Culture is also helpful. While $25 \%$ of respondents stated that they don't have money to provide quota.

The last conducive learning environment is parental support. More than one hundred or about twothirds of respondents chose the answer often and always to indicate parental support during online learning. This support is in the form of always reminding them to attend the online study schedule, do assignments, etc. On the other hand, there were a small number of students who stated that their parents were not supportive by asking students to help their parents during online study hours, never reminding them because their parents were busy, and asking students to take care of their younger siblings.

From the explanation above, it can be concluded that the quite high motivation to learn French during the Covid-19 pandemic is mainly due to the desire and desire to succeed, to be diligent in facing assignments, and also to be tenacious in facing assignments. All of this is shown by students who tend to always be present in learning, participate actively in the class, feel a loss to skip French class, do assignments independently, answer all the questions. In addition, students also never give up when faced with difficult assignments because they have better grades.

Previous studies on learning motivation, especially during the Covid-19 pandemic, showed different results. Research conducted by [11] showed that students' learning motivation during the online learning process decreased. Meanwhile, [15] who examined student motivation during online learning showed very good results. On the other hand, a study conducted by [16] on students of SMAN 2 Mendoyo Bali revealed that students' learning motivation during online learning was in the moderate category.

Motivating students is one of the toughest tasks that must be faced by a teacher. Many things affect it, including teacher competence. This is strengthened by a statement of [17] that teacher competence and learning facilities are factors that influence student learning motivation.

In addition, there is also a learning climate. The learning climate created by online learning also affects student learning motivation. In offline learning, the teacher must be able to create a conducive classroom atmosphere to maintain student learning motivation so that learning can be achieved because the classroom climate has a significant influence on learning motivation [18]. 
Several other efforts can also be made by teachers to increase learning motivation, namely by clarifying the goals to be achieved, generating student motivation, creating a pleasant learning atmosphere, using a variety of attractive presentation methods, giving reasonable praise for each student's achievement, providing assessments, providing comments. on the results of student work and create competition and cooperation [19]

Concerning learning a foreign language, one way is by introducing the culture of the target language. Several studies have proven the relationship between culture and language, including Malinowski (1944) in [20] which states that a good understanding of language is impossible to achieve without connecting the learning of the target language with its culture. In other words, language learning cannot be separated from culture. Furthermore, [32] explains 'as learners learn about the language they learn about the culture and as they learn to use a new language, they learn to use a new culture'. According to Kitao as quoted in [21] Gardner and Lambert have proven that lessons about culture can motivate students because learners like to do cultural-related activities and learn about other people. They also show that the study of culture will increase their curiosity and interest in other people.

\section{B. Correlation between motivation and learning outcomes}

The second objective of this study was to determine the correlation between motivation and student achievement during online learning of Covid19. The value of motivation is obtained by calculating the results of the questionnaire for 18 statement items. This learning motivation is the independent/independent variable symbolized by $(\mathrm{X})$ while learning outcomes are the dependent variable or (Y). Scores for learning achievement are obtained from the PAT (End of Year Assessment) scores of students from each school.

The hypotheses in this study are a) Hypothesis Zero (Ho): There is no correlation between motivation and student achievement during language learning during the Covid-19 pandemic and b) Research Hypothesis (Ha): There is a correlation between motivation and student learning outcomes during study language during the Covid-19 pandemic. Before getting to the hypothesis test, there are several tests carried out, namely normality and linearity. This study uses the help of SPSS 19 for calculations. After getting the results of the normality test and linearity test which states that the data used in this study are normally distributed and the learning motivation variable has a linear relationship with learning outcomes, the next step is a hypothesis because the prerequisite tests have been met.

Hypothesis testing is used to prove there is a correlation between motivation as an independent variable $(\mathrm{X})$ and students' French learning outcomes during the Covid-19 pandemic as the dependent variable (Y). This test uses the Product Moment correlation test with the help of the SPSS 19 program. Based on the calculated r-value (Pearson Correlations) it is known that the calculated r-value for the relationship between Motivation (X) and Achievement (Y) is $0.224>\mathrm{r}$ table $0.194(\mathrm{~N}=164)$, then it can be concluded that there is a relationship or correlation between the motivation variable (X) and learning outcomes (Y). Then, because $r$ arithmetic or Pearson Correlations in this analysis is positive, it means that the relationship between the two variables is positive, or in other words, the higher the motivation, the higher the student learning outcomes.

The correlation coefficient between the two variables is 0.224 . Referring to the guideline table for interpreting the correlation coefficient from [12], the number lies in the interval $0.20-0.399$. So it can be concluded that the relationship between the two variables is low.

Many experts and research results have successfully confirmed that motivation has an important role in success in learning [22;23;24], The results of this research also strengthen the conclusion that higher motivation will increase student learning outcomes. However, the results of the PAT (End of Year Assessment) results of 164 respondents are still far from the standard, which is $48.5 / 100$. It turns out that high motivation does not guarantee good results or at least achieve standard grades in school (KKM).

As quoted from [11] several factors influence learning motivation, including psychological factors in which there is an element of attitude. Attitude in the context of learning motivation is defined as a happy state or atmosphere, good teacher teaching methods and so on can make students enthusiastic so that they get maximum results, and vice versa. Opinions about the role of attitude on motivation were also conveyed by Gardner and Lambert cited by $[25 ; 26]$.

Interviews aimed at exploring in-depth information regarding this matter revealed that $71 \%$ of respondents stated that they quite liked French. The preference for French is because students have an interest in learning foreign languages, some also think that French is unique, while a small number of respondents say they want to continue their studies in France. Despite having an interest and liking for this language, almost all students think that French is difficult to learn, especially in pronunciation and orthographic or writing systems that are very different from pronunciation so that respondents often find it difficult to understand.

French for all respondents is the second foreign language learned after of course English. Although this language has many similarities with English in terms of vocabulary, it has a different complexity from 
English in terms of grammar and pronunciation as well as the use of diacritical marks in writing which is also different. So when starting to learn a completely new language but is done by emphasizing only on grammar and vocabulary with assumptions like English that students have learned since elementary school, it is not surprising that students think French is difficult.

According to its nature, language is a sound that is used as a means of communication. These language sounds are the initial foundation of language learning and this is where the teacher's role in teaching foreign languages is. The teacher is positioned as a model to be imitated. Therefore, it is very important to teach a new language directly at the beginning of learning, so that students have a fairly strong foundation.

Although there are many articles, websites, or videos on the internet about learning French, it seems that students do not take advantage of them. Students only focus on the material and assignments given by the teacher. The use of the internet for self-study is generally limited to machine translation (google translate). In this case motivation alone in online learning is not enough, independent learning is also needed, confidence in using the internet is also needed. This is also confirmed by Hung et al (2010) in [15], namely that several notes must be considered so that online learning remains optimal, which is related to learning readiness including confidence in the use of computers/internets, independent learning, learner control. , motivation to learn and confidence in online communication

In addition to the difficulty of pronouncing and writing French, another thing that affects the PAT score that is less than the standard is related to the assessment. As is well known, assessment is an important part of learning. Not only as feedback for teachers or institutions to measure the success of the educational program itself, but it is also very important from the student's point of view. Assessment can stimulate student activities in taking educational programs. With assessment, students can improve and improve their respective achievements [27]. This is also confirmed by Brown (2001) and Snowman (1997) in [20] who say that students will be motivated to pursue a goal (good grades) if they are rewarded for completing the task.

The students' low PAT (End of Year Assessment) results are also related to this aspect. The assessment and return of student assignments at the end of the semester do not allow students to measure and improve themselves. Students cannot learn from their mistakes. In this case, the teacher should correct and return the results of student work or assignments on time as a form of appreciation for student efforts and can be a benchmark for students about their achievements so that they are expected to motivate students more in learning.
Assessment is not just giving numbers. Not all assessments can motivate students. Dissatisfaction with grades, especially a lack of understanding of how the assessment is taken, can give students negative emotions and can reduce their desire to learn. Only assessments that provide reliable information about the level of achievement that allow students to know their level of mastery in a material know where they went wrong and understand what to do to improve themselves have a positive effect on increasing student motivation [28]Similar to this opinion, Brown (2001) and Snowman (1997) in [20] that it is important to reinforce student behavior with words of encouragement, praise, or positive comments.

The government provides leeway for education units to determine the basic competencies that must be provided during this pandemic and provide the option to form an emergency curriculum. In practice, many teachers and schools adopt this online learning by reducing the number of competencies that must be provided. The two schools involved in this study also reduced the number of basic competencies in the French class X syllabus 2013 curriculum and each school chose to provide a different number of basic competencies.

Assessment cannot be separated from planning and implementation. Assessment should be based on predetermined goals and implementation throughout the program. The PAT assessment is carried out at the end of the even semester with the material for all basic competencies taught in the even semester. From the analysis of assignment documents, it is known that the questions tested are not only from basic competencies in even semesters but also from odd semesters. The sequence and planning of giving basic competencies during the even semester were not realized properly. In short, teachers are not well prepared for teaching during this online learning. Assessment cannot be separated from planning and implementation.

Moreover, the use of teaching media also contributes to the success of learning. Fasold and Connor-Linton (2000) in [20] explain that varied and challenging learning activities help students to concentrate and be actively involved in learning and can facilitate the process of learning a second language. Based on interviews, it is known that the media and teaching materials used by teachers are quite varied. In addition to French handbooks, videos taken from YouTube, French songs, handouts in the form of slides also add to the diversity of student learning media. However, the majority of students said this learning technique was not interesting because of the lack of teachers exploring the media for learning. Giving and collecting assignments are the mainstay of activities carried out by teachers with minimal explanation and sometimes without explanation. Therefore, not a few students have difficulty and rely on the google translate machine translator to 
understand the sentences they read. Although there are teachers who try to explain using voice notes on WAG, it is not enough to make students understand.

The interview also reveals the students' opinions about the preferred learning. It is known that $98 \%$ of students prefer offline or face-to-face learning. The main reason for the students is that they find it difficult to understand the subject matter. In addition, respondents also stated that their French language skills cannot be honed well during online learning, especially competencies that do require direct interaction such as speaking and listening. The ability to write and read is not problematic enough because of the ease with which they can access Google Translate to support their mastery of these competencies.

The quality of online learning can hardly be equated with offline as in the opinion of [29] that the quality of learning during the pandemic period has decreased. From the description above, it can also be concluded that motivation and learning outcomes do have a positive relationship, but motivation alone is not enough to get good learning outcomes because motivation also requires the right approach to be useful in the learning process [20] Many factors that influence this success and the success or failure of a goal in learning is very dependent on the process of implementing the learning itself.

\section{CONCLUSION}

Although learning French is carried out online with various problems and limitations, the results of the questionnaire show that students' learning motivation is still in the good category, which is 79.7 seen from six indicators, namely diligent in facing assignments (86.46), the desire and willingness to succeed $(85,85)$, tenacious in facing difficulties (83.53), interesting activities in learning (75.73), conducive learning environment (73.29) and encouragement and needs in learning (73.17). With the help of the SPSS 19 program, hypothesis testing showed that there was a positive relationship between motivation $(\mathrm{X})$ and learning outcomes (Y). This low correlation coefficient can be explained by the fact that although most of the respondents quite like French, they find it difficult to understand the material due to the lack of teacher explanations and the teaching system which is dominated by assignments. This is expected to get more attention from teachers, especially in this case teaching a completely new foreign language.

\section{REFERENCES}

[1] Chalak, A, Kassaian, Z, 'Motivation and attitudes of Iranian undergraduate EFL students toward learning English,' GEMA Online : Journal of language studies, 10 (2), 2010

[2] Ellis, R, 'Second Language Acquisition,' New York : Oxford University Press, 1998

[3] Martha, I.N., Sriasih, S.A.P., Indriani, M.S., 'Analisis Hubungan Sikap dan Motivasi terhadap prestasi belajar bahasa Bali mahasiswa baru Jurusan Pendidikan Bahasa Bali Tahun Ajaran 2013-2014 (Studi Psikometerik dalam Rangka
Rekrutmen Mahasiswa Baru Jurusan Pendidikan Bahasa Bali),' PRASI, 8(16). 2013

[4] Sudirman \& Huzairin, 'Sikap Bahasa Siswa SMP dan SMA terhadap Pembelajaran Bahasa Inggris di Kota Bandar Lampung,' AKSARA : Jurnal Bahasa dan Sastra 18(1), pp.44-45, 2017.

[5] Kholid, I, 'Motivasi Pembelajaran Bahasa Asing,' English Education : Jurnal Tadris Bahasa Inggris, 10(1), 2017.

[6] Quinto, E. J. M, 'Attitude and Motivation towards a Working Language : Case of East Timorese Students in the Philippines, The Southeast Asian Journal of English Language Studies 21(1), 1-12, 2015 . DOI : 10.17576/3L2015-2101-01

[7] Brown, H. Douglas, 'Principles of Language Learning and Teaching,' USA: Longma, 2007

[8] Brown, H.D., 'Intrinsic motivation in the classroom teaching by principles . 2nd edition,' Sam Fransico : Education, 2017

[9] Anugrahawati, R. \& Silitonga, J, 'Pendidikan jarak jauh (PJJ) saat wabah Covid-19 memengaruhi motivasi belajar mahasiswa akademi keperawatan Hermina Manggala Husada,' Jurnal Ilmiah Keperawatan Altruisik (JIKA), 3 (2), pp. 10-16, 2020

[10] Jamil, S. H \& Aprilisada, I. D, 'Pengaruh pembelajaran daring pada masa pandemic covid-19 terhadap minat belajar,' Behavioral Accounting Journal (BAJ), 3 (1), pp. 37- 46, 2020

[11] Cahyani, A., Listiana, I.D., Larasati, S.P.D, 'Motivasi belajar siswa SMA pada pembelajaran daring di masa pandemi covid-19,' IQ (Ilmu Al-qur'an Jurnal Pendidikan Islam, 3(1). pp.123-140, 2020. DOI:10.37542/iq.v3i01.57

[12] Sugiyono, 'Metode Penelitian : Kuantitatif, Kualitatif dan R\&D,' Bandung : Alfabeta. 2017

[13] Uno, Hamzah. B, 'Teori Motivasi dan Pengukurannya,' Jakarta : Bumi Aksara, 2016

[14] Sardiman, 'Interaksi dan Motivasi Belajar dan Mengajar,' Depok : Rajagrafindo Persada. 2016

[15] Fitriyani, Y. Fauzi, I \& Sari, M.Z, 'Motivasi Belajar pada Pembelajaran Daring Selama Pandemik Covid-19,' Jurnal Kependidikan : Jurnal Hasil Penelitian dan Kajian Kepustakaan di Bidang Pendidikan, Pengajaran dan Pembelajaran, 6(2). Pp. 165-175. 2020

[16] Winata, I. Komang, 'Konsentrasi dan Motivasi Belajar Siswa Terhadap Pembelajaran Online Selama Masa Pandemi Covid19,' Jurnal Komunikasi Pendidikan, 5(1). 2021 pp.13-24

[17] Werdayanti, A, 'Pengaruh kompetensi guru dalam proses belajar mengajar di kelas dan fasilitas terhadap motivasi belajar siswa,' Dinamika Pendidikan 3(1). 2008

[18] Sari, D.P. \& Rusmin, A.R, 'Pengaruh iklim kelas terhadap motivasi belajar peserta didik di SMAN3 Tanjung Raja,' Jurnal Profit Kajian Pendidikan Ekonomi dan Ilmu Ekonomi 5 (1), h. 80-88. 2018

[19] Surpihatin, S, 'Upaya guru dalam meningkatkan motivasi belajar siswa,' Jurnal Pendidikan Ekonomi 3(1), h.73-82. 2015

[20] Mantiri, O, 'Principles in Language Learning Motivation,' Linguistics and litteratur studies, 3(2) : 70-74. 2015. DOI : 10.13189/IIs.2015.030206

[21] Genc, B. \& Bada, E, 'Culture in language learning and teaching,' The Reading Matrix, 5(1). Diakses tanggal 12 Agustus 2021 dari http://www.readingmatrix.com/articles/genc_bada/article. pdf

[22] Slameto, 'Belajar dan Faktor-Faktor yang mempengaruhinya,' Jakarta : Rineka Cipta, 2010.

[23] Dalnyono, Psikologi Pendidikan,' Jakarta : Rineka Cipta. 2010

[24] Emda, A, 'Kedudukan siswa dalam pembelajaran,' Lantanida Journal 5(2), 2018 
[25] Richard-Amato, P.A, 'Integrating educational technology into teaching (3rd ed.),' New York : Pearson Prentice Hall, 2005

[26] Mahmoudi, S \& Mahmoudi, A, 'Internal and External Factor Affecting Learning English as a Foreign Language,' International Journal of Language and Linguistics, 3(5). pp.313-322. 2015. DOI:10.11648/j.iji1.20150305.16

[27] Sudijono, Anas, 'Pengantar Evaluasi Pendidikan,' Jakarta : Rajagrafindo Persada. 2015

[28] Efremova, N., Shvedova, S. \& Huseynova, A, 'The influence of assessment on learning motivation,' SHS Web of Conference, 2019, DOI : 10.1051/shsconf/20197004003

[29] Sahu, P, 'Closure of Universities due to Coronavirus Disease 2019 (COVID-19) : Impact on Education and Mental Health of Students and Academic Staff,' Cureus, 2019 (April). DOI : 10.3991/iket.v9i4.3465

[30] Cheng, H., and Dörnyei, Z, 'The Use of Motivational Strategies in Language Instruction: The Case of EFL Teaching in Taiwan,' Innovation in Language Learning and Teaching, Volume 1 Number 1, 153-174, 2007.

[31] Dörnyei, Z., and Csizér, K, 'Ten Commandments for Motivating Language Learners: Results of an Empirical Study,' Language Teaching Research, 2 (3), 203-229, 1998.

[32] Byram, M, 'Cultural Studies in Foreign Language Education,' Clevedon: Multilingual. Matters Ltd, 1989. 